\title{
Conceptual Approaches to Formation and Development of the Collaborative Model of the National Innovation System of Latvia
}

\author{
Mg. Oec. Konstantins Savenkovs \\ Ltd "LBK" College and Ltd "EDU", Latvia
}

Copyright $(2016$ by authors, all rights reserved. Authors agree that this article remains permanently open access under the terms of the Creative Commons Attribution License 4.0 International License

\begin{abstract} without widespread implementation of innovations, so it is time to take a fresh look at the development of the economy as a whole, because we are talking about the system transition, or rather about changing the system paradigm. Such a change involves the formation of a new model of the national innovation system, namely the creation of advanced technology using human capital and science, their commercialization through the introduction in the production of dynamic regional companies and industries in a symbiotic relationship with the state. The new paradigm of economic development implies the need to build a national innovation system, which, in turn, provides an overall cost savings, changes in the structure and growth of the economic system as a whole (or parts thereof), in the medium and long term perspective. In this case, the requirement of time - a new network model of innovation that created different communities parties entering into a relationship of collaboration and forming a specific ecosystem (collaborative innovation networks). Increased plasticity of national innovation systems is intended to give them the ability to self-development on the basis of continuous updates, to make economic growth innovation-oriented, and the country more competitive.
\end{abstract}

Keywords National Innovation System, The Ecosystem Approach, Collaborative Model

\section{Introduction}

Against the backdrop of the intensification of the development of innovative schemes, structures and improving management processes in both developed and developing countries have shown a significant backlog of Latvia, which is confirmed by the indicators of competitiveness in international economic ratings (Global Innovation Index, and others.).
Preliminary studies confirm the fact that the increase in national competitiveness is impossible without the creation of a national innovation system. Formation of NIS requires, as the experience of small European countries, restructuring, rationalization, restructuring and possibly of its components, and the relationships between them, based on a new paradigm of economic development.

Article aims to develop a model of innovation system of Latvia, contributing to improve its competitiveness.

The importance and innovation of the article. The theoretical significance of the results of the study lies in the fact that the reasonable scientific statements in the article and conceptual approaches enable a better understanding of the formation and development of the national innovation system. The practical importance is the concrete proposals on the methodology and the construction of a modern model of national innovation system of the Republic of Latvia.

Innovativeness of the article is in the system authoring collaborative model of the national innovation system of Latvia and its evolution.

\section{Brief Literature Review}

The first systematic and theoretical study of national innovation systems (NIS) refers to Friedrich List (FriedrichList, «Das Nationale Systemder Politischen Ökonomie», 1841). His contribution is interesting in that it has developed an alternative view of Adam Smith and his modern followers. Friedrich List (1841) makes a distinction between "cosmopolitan" approach of Adam Smith, which focuses on sharing and distribution and its own national perspective based on the development of the productive forces. [1].

The first explicit use of the national innovation system concept can be found in one of the books of K. Freeman about Japan (Freemans.1987). Freeman's emphasis on the institutional context for innovation, stressing that NIS represent a kind of "network of institutional structures in the 
public and private sectors, activity and interaction which initiates and creates, modifies, and contributes to the diffusion of new technologies" [2].

A significant contribution to the conceptual evolution of the ecosystem approach were represented in works of B. Mercan, D. Goktas ( «Components of Innovation Ecosystems: A Cross-Country Study», 2011). The term "ecosystem" is borrowed from biology economists - along with the concept of "ecology". In the economic context of the ecosystem approach is considered as a concept that describes the evolution of the nature of the interactions of economic agents, models of their innovative activity and the relationship with the operational environment. The ecosystem approach considers the innovation systems at all levels (national, regional, cluster and others.), as a living social organism, subject to continuous variation under the influence of the new motivations of participants and new circumstances. In this perspective, innovative ecosystem looks not only as a dynamic set of organizations and institutions, but also as a mobile set of their multidimensional internal bonds. The prefix "eco" (in relation to the "system" concept) indicates in this case that in modern conditions collectively innovations originate in a specific network environment, based on the horizontal (non-hierarchical) relationships legally independent participants [3].

The concept of the "triple helix" originated in England and the Netherlands at the beginning of the XXI century, its ideologists considered professor at the University of Newcastle Henry Etzkowitz and professor of the University of Amsterdam Loet Leydesdorff. The concept of the "triple helix" shows inclusion of the interaction of certain institutions at every stage of the creation of an innovative product [4].

The concept of 'collaboration' represents the ultimate, interactive form of cooperation, and comes from the word 'laboratory', reflecting the nature of the relationship, once established in the American Silicon Valley laboratories. In the literature under the collaboration understand the "process of formal and informal agreements between autonomous players, during which they establish joint rules and organizations to manage their interactions and activities, or decide to combine their tasks" [5].

\section{The Main Results of the Research}

The primacy of this study - the ecosystem approach in the framework of the "triple helix" in the collaboration of the national innovation system of Latvia. In order to assess this interaction the national innovation systems in the European Union were analyzed, is considered the Latvian economy after joining the EU and characterized by efficiency of existing NIS.

In a study of the formation and development of national innovation systems in the EU, it has been proved that NIS European countries differ greatly from each other in setting goals and objectives, their achievements, and have a common problem in the structure of allocations for research and innovation. This conclusion was based on the study of the European project «From Challenges to Opportunities: Towards a Common Strategic Framework for EU research and innovation funding», as well as the Framework (The Framework Programme for Research and Innovation "Horizon 2020".

One can say with certainty that for the establishment and development of national innovation systems in the EU should be a closer link between national institutions, business initiatives and pan-European programs. Also, it will help Latvia go abroad from the modest to moderate innovators. It was revealed that at present most of the wealthiest countries in the world - it's the small states of Western and Northern Europe.

So Scandinavian countries, along with the economy of Switzerland, are the leaders in terms of economic development (Table 1). One of the main reasons for the high stability of these economies is taken a few decades ago in the course of construction of the new age economy - an economy based on innovation.

Table 1. Small highly developed European countries rating

\begin{tabular}{|c|c|c|}
\hline Rating & Country & $\begin{array}{c}\text { Index } \\
(0-100)\end{array}$ \\
\hline 1 & Switzerland & 68.3 \\
\hline 3 & Sweden & 62.4 \\
\hline 6 & Finland & 60.0 \\
\hline 10 & Denmark & 57.7 \\
\hline 20 & Norway & 53.8 \\
\hline
\end{tabular}

Made by the author on the basis of data The Global Innovation Index [6]

The interest in the experience of innovative development in these countries due to the fact that in the past decade, these countries are characterized by high levels of innovation development. They consistently occupy a leading position in the ranking of the competitiveness "of the World Economic Forum 2015", based on the "Global Competitiveness Index 2015". One may agree that a large government size is not a prerequisite for high competitiveness on the world market and the growth of labor productivity. On the contrary, their value can lead to political, economic, administrative and economic-territorial inertia. Also, small countries can successfully implement its competitiveness in areas where entrepreneurship in large countries would be unprofitable. 


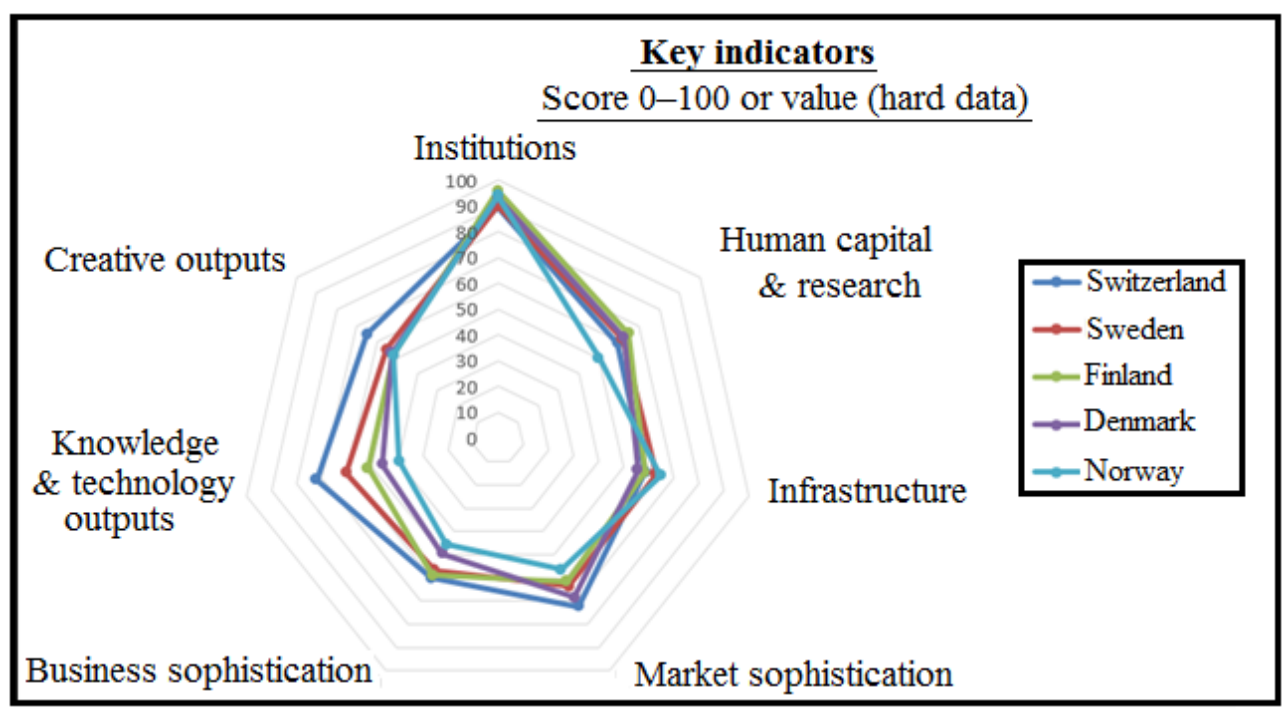

Made by the author on the basis of data The Global Innovation Index [6]

Figure 1. Small highly developed European countries rating on the basis of the NIS model key "core" indicators

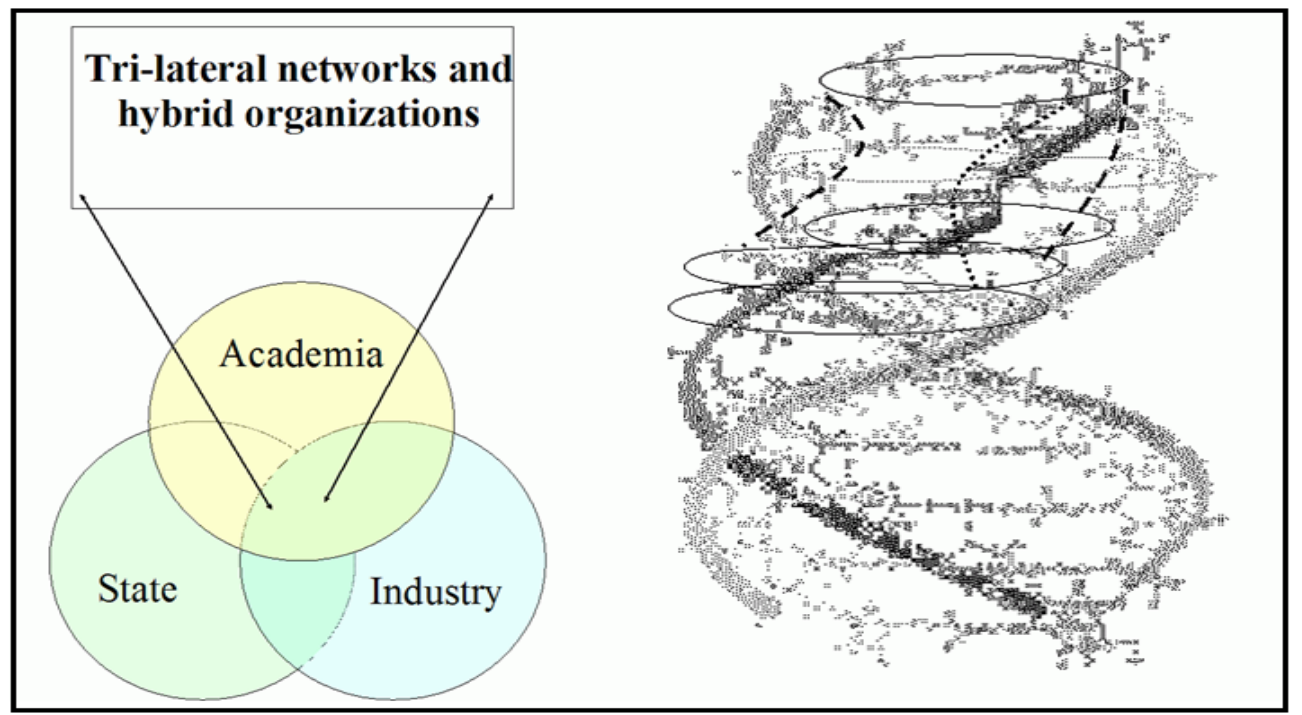

Made by the author based on the Dynamics of Innovation: from National Systems and "Mode 2" to a Triple Helix of University-Industry-Government Relations [7]

Figure 2. The Triple Helix Model of University-Industry-Government relations

The systematization and sectioning 81 of the indicators of "Global Innovation Index" (which describes both direct and indirect, of successful interaction NIS entities) in the major groups: institutions; Human capital and research; Infrastructure; Development of the market; Business development; Out of knowledge and technology; Creative outlets - small-leader countries have been identified in the innovative development, these are: Sweden, Finland, Denmark, Norway and Switzerland (Figure 1). There was also proved their success, which is based on historical experience, where the key was the economy based on knowledge, which has a national character. These countries have in the recent past docked economic policy, science and business, have built them based on comparative advantage and as a result got a new regional economy, competitiveness and innovation in fact, not declarative.
With the spread of information and communication technologies and increasing customization of production, innovations become interactive, and the economy draws new sources of growth and development on the level of the different groups of society in the scale of society as a whole. On this basis, it was rethought view of the NIS and the adoption of a new paradigm of the network model of innovation, which is created in conjunction with members of various online communities, entering into a relationship of collaboration and the formation of a particular ecosystem collaborative innovation networks (Figure 2).

"Triple Helix" is considered to be a universal model of collaboration, as it creates a mechanism of self-development of complex nonlinear systems at all levels, based on the resonant interaction of three key subsystems. By displacing traditional control mechanism involving hierarchical center, 
this model defines a new institutional set-up of the innovation system. Through continuous interaction between the state, business and science in the system of work enough new knowledge that is distributed in the communication between all economic agents, which gives the system integrity and dynamic stability [8]. However, it was theoretically proved that the concept of the "triple helix" collaboration in the national innovation system is not always sufficient. There may be a fourth element for the development of NIS.

The concept of "Fourth helix" has been described by Y. Karayannis and D. Campbell in 2009. The fact that the innovation process is influenced by other institutions, representing different social strata, found theoretical expression in the addendum to the fourth element of the triple helix. The fourth spiral in this case refers to the civil society, which has an impact on culture, the media, arts, values, lifestyle, creative industries, as well as possible, "creative class". [9]. The overall results of statistical analysis of the economic development of Latvia for the period of ten years (2004 - 2014) proved that all the parameters were shown only in one direction - from the EU to Latvia. The author's SWOT - analysis of innovation system of Latvia from 2004 to 2014 revealed the following weaknesses:

- Inactive development of EU funds;

- A small number of employees in the research enterprise sector;

- Reduction of students and graduates;
- Reduction in received academic and professional master's degrees;

- A small share of innovation - active enterprises;

- A small amount of expenditure on R \& D and innovation (\% of GDP);

- Falling R \& D in enterprises in the manufacturing industry and around the workplace;

- Not regulated structure of science, technology and innovation system management of Latvia;

- Insufficient level of scientific research and development of innovative enterprises;

- Almost no registration of patents in the absence of innovation;

- Low mobility of scientists and a large "brain drain";

- Poorly developed R \& D;

- Unformed national innovation system.

All this indicates that there is a lack of a national innovation system. The way out of this situation would be the creation of a model of NIS, which reflects the historical features of the development of the country, the conditions of its functioning and will be based on the experience of the smaller European countries.

Considering the evolution of the triple helix model in the Latvian economy it can be divided into three main stages: before the collapse of the USSR (until 1990.), after the collapse - the formation of the independent Latvia (since 1990-ies.), and after Latvia joined the European Union since 2004 (Figure 3).

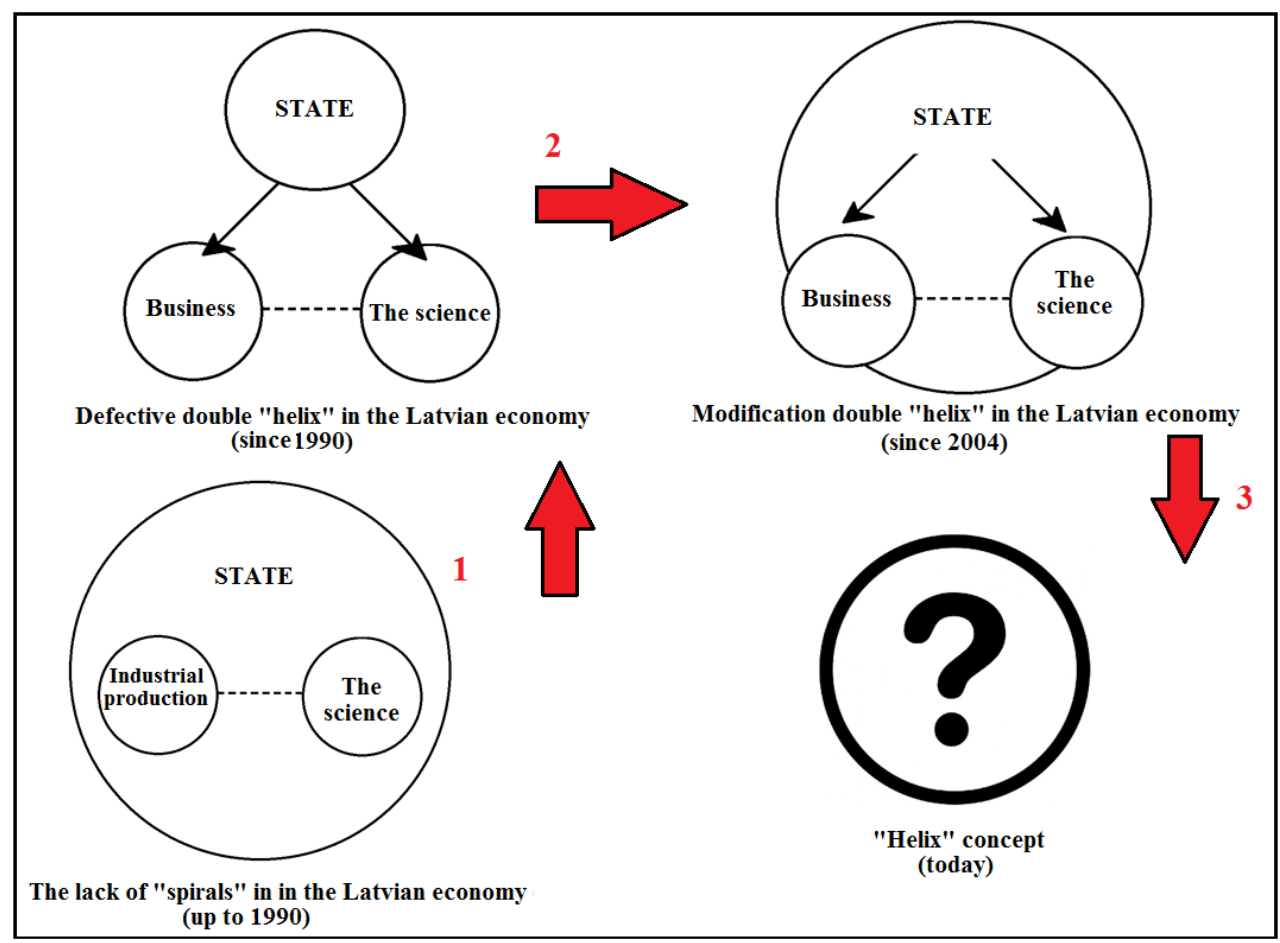

Made by the author

Figure 3. Evolution of the "spiral" in the Latvian economy (The Triple Helix) 
Evolution of the "spiral" concept in the Latvian economy has passed through three stages. It is proposed to re-think and to add a fourth element - the human capital. Evolution of the "spiral" is similar to the DNA conformation (two, three or four spirals).

To create a model of the national innovation system of Latvia the concept of a "quadruple helix" was formed, it was included in the calculation scheme (a triad - a triple helix) integral fourth indicator - "Human capital and research", not previously taken into account criteria for its overall assessment.

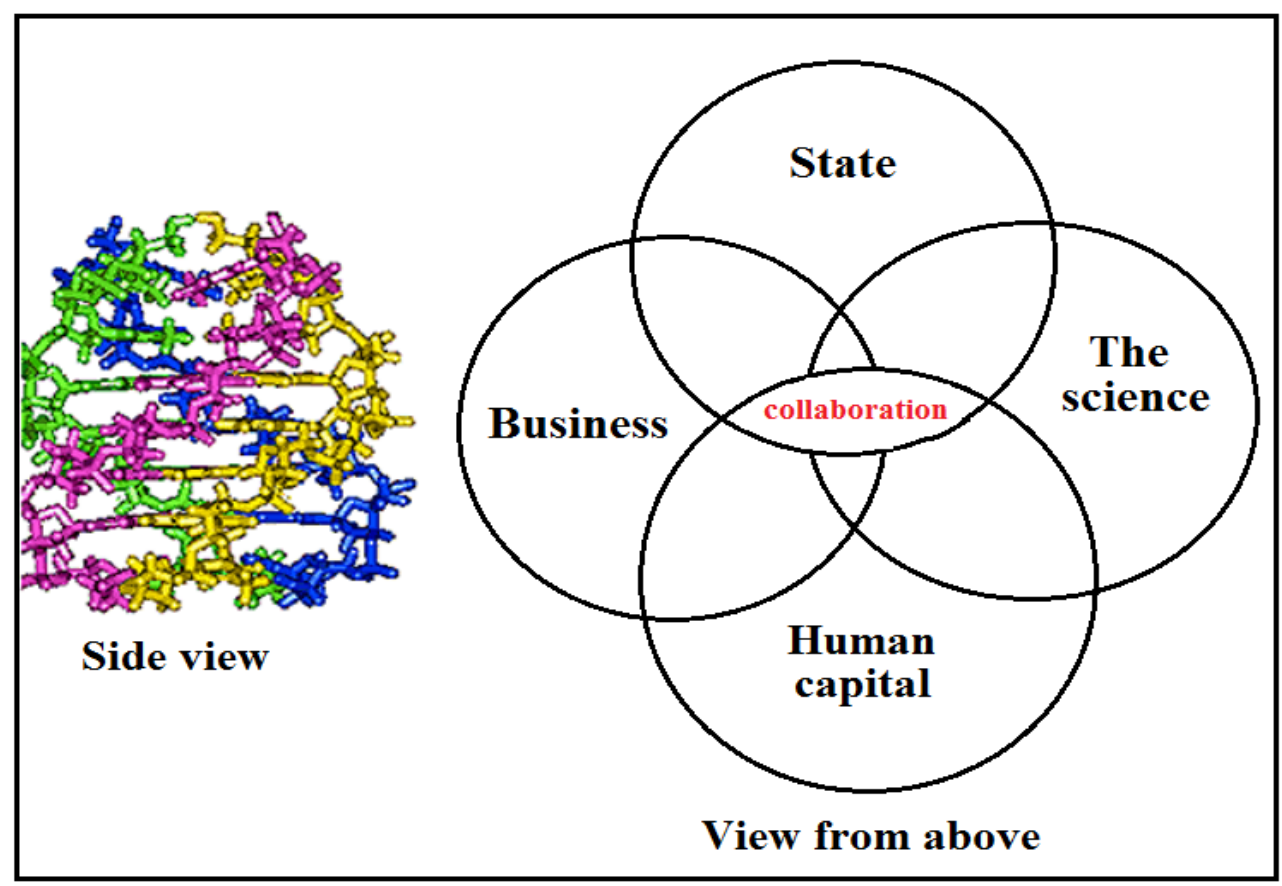

Made by the author

Figure 4. The concept of "Fourth helix"

This indicator has been selected on the basis of the analysis (Figure 5) which showed that it was "Human capital and research" has the weakest performance in Latvia (33.1), which inhibit the formation and development of the national innovation system. That is a resource that in Latvia is simply not used. Human capital refers to the intensive factors of economic growth and is determined to improve and enhance the quality of management, technology, using innovation modernization of production.

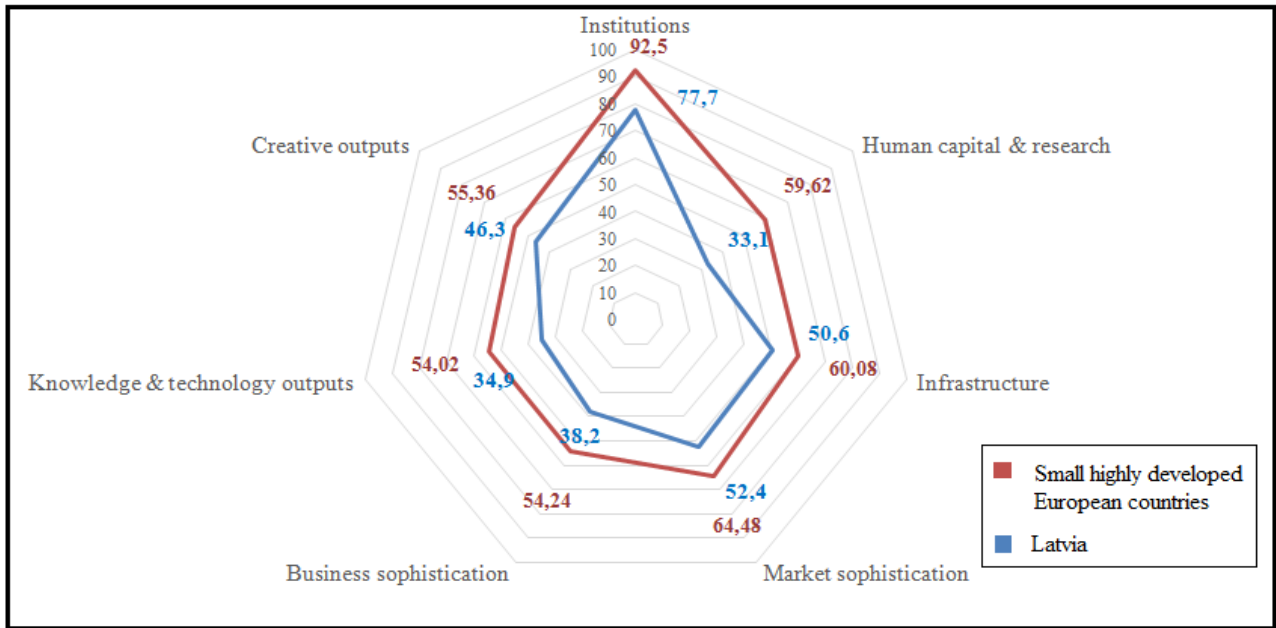

Made by the author on the basis of data The Global Innovation Index [10]

Figure 5. The evaluation of the "core" model of NIS Latvia on the basis of the average key indicators "Global Innovation Index 2015" small highly developed European countries

Using the ecosystem approach within the already "quadruple helix" has been developed collaborative model of the national innovation system of Latvia (Figure. 5). The main factor of growth and intensive development of the economy as the industrial and innovation is high-quality human capital. 


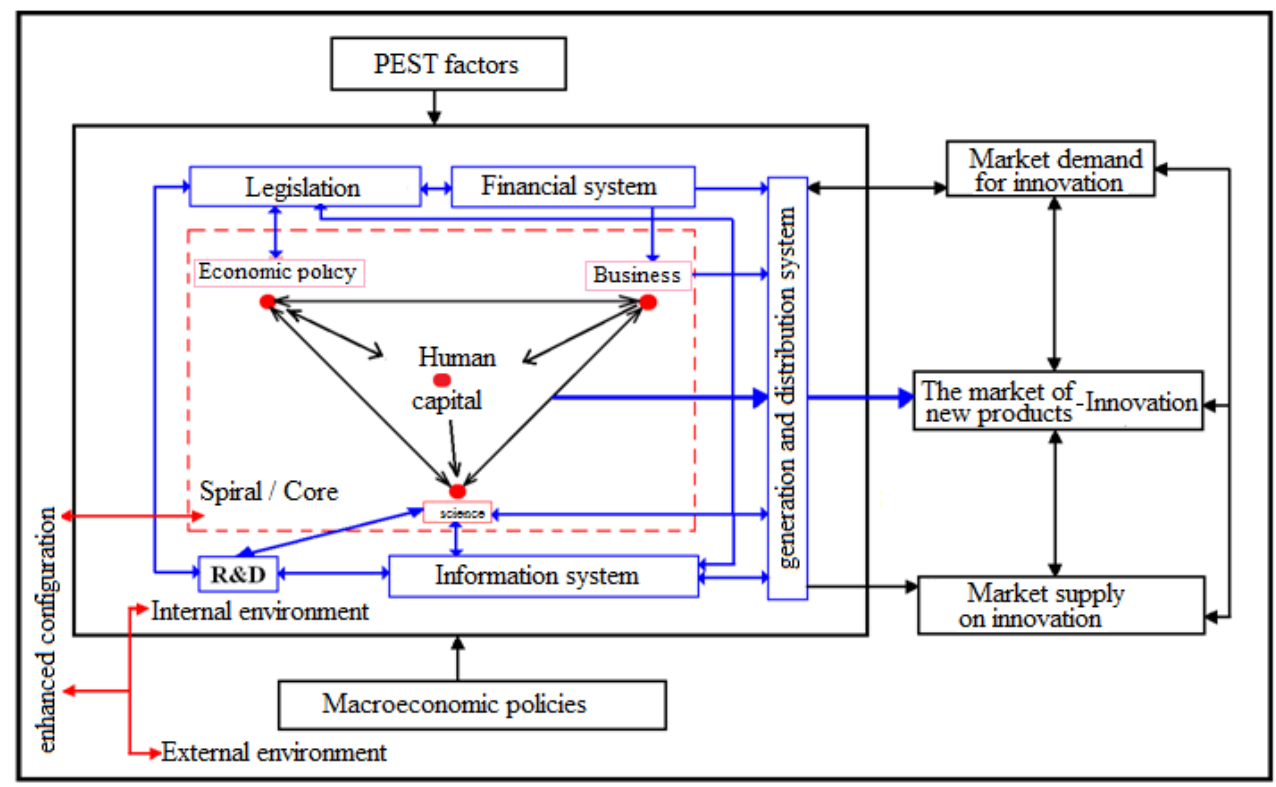

Made by the author

Figure 6. Collaborative model of the national innovation system of Latvia

There is a spiral in the form of a core in a triangular format, where the main position is a new actor - is the human capital.

The new model of Latvian NIS will give a hope for a qualitative change of the economy (in the region), the increase of its competitiveness on the domestic and foreign markets, which in turn, will create the internal conditions for the emergence of new sectors with a minimum cost of production, creating new jobs and raising living standards of the population in the long term. Connecting the economic politics, science, business and human capital, building them based on comparative advantages, would be possible to create a new regional economy - competitive and innovative.

\section{Summary and Concluding}

The research supports the fact that the increase in national competitiveness in Latvia is impossible without the creation of a national innovation system. The formation of the collaborative model of the national innovation system of the country will require a rethinking, restructuring, rationalization and restructuring of all components and the relationships between the elements of the national innovation system.

A new systematic approach to the formation of the national innovation system model takes into account the effect, as the level of development of the subjects of the national innovation system and its specifics and peculiarities of the country on the implementation of innovative changes and generates new institutions.

The transition to a new paradigm of innovation going on in parallel with the revaluation of human capital as the main factor of production, as well as key values for any country and even individual companies. Competition now moves from the area of finished products in the field of knowledge, scientific discoveries and advanced technologies. So, an information society and economy based on knowledge occurs. The main generator and at the same time the consumer of innovations, as well as the national supplier of innovation in foreign markets is high technology business. Thus, the high technology business in most developed countries is the foundation of national competitiveness in international markets.

\section{REFERENCES}

[1] Lundvall, Bengt-Åke, ed. National systems of innovation: Toward a theory of innovation and interactive learning. Vol. 2. Anthem Press, 2010 P. 17

[2] Freeman, Freeman, C., 1987. Technology Policy and Economic Performance: Lessons from Japan, Pinter, London. P.1

[3] B. Mercan, D. Goktas. Components of Innovation Ecosystems: A Cross-Country Study//International Research Journal of Finance and Economics, No 76, 2011.

[4] The Triple Helix concept. URL: http://triplehelix.stanford.edu /3helix_concept

[5] A. M. Thomson, J. L. Perry. Collaboration Processes: Inside the Black Box//Public Administration Review. Vol. 66.N. s1, 2006.

[6] Soumitra Dutta, Bruno Lanvin, and Sacha Wunsch-Vincent «The Global Innovation Index 2015: Effective Innovation Policies for Development», p. 16

[7] The Dynamics of Innovation: From National Systems and "Mode 2" to a Triple Helix of University-Industry-Governm ent Relations. URL: http://www.leydesdorff.net/rp2000/

[8] L. Leydesdorff. The Triple Helix of University-Industry- 
Government Relations/in E. Carayannis, D. Campbell (eds.). Encyclopedia of Creativity, Innovation, and Entrepreneurship, New York: Springer, February 2012.

[9] Касенов Р.P Модель национальной инновационной системы // Вестник Челябинского государственного университета. 2013. № 32 (323) Экономика Вып. 52-56 с. - c. 55 URL: http://www.lib.csu.ru/vch/323/009.pdf

[10] Soumitra Dutta, Bruno Lanvin, and Sacha Wunsch-Vincent «The Global Innovation Index 2015: Effective Innovation Policies for Development», p. 231 